\title{
Strategic Difference Degree, Industry Competition Degree and Enterprise Performance
}

\author{
Sunlei Yang*, Qian Li and Qi Zhou \\ Accounting College, Wuhan Textile University, Wuhan China \\ *Corresponding author. Email:50495815@qq.com

\begin{abstract}
Strategic difference degree and industry competition degree are two essential factors to be considered in enterprise operation. In a highly competitive market, there are many ways for enterprises to improve their performance. However, there is no conclusion on the influence of strategic difference degree on enterprise performance in the existing literature, so its influence needs further discussion. On the basis of measuring enterprise strategic difference degree, industry competition degree and enterprise performance, this paper empirically studies the relationship among the three, and obtains the research results.
\end{abstract}

Keywords: Strategic difference degree, Industry competition degree, Enterprise performance.

\section{INTRODUCTION}

In the face of the ever-changing market, enterprises are making more and more diversified strategies. Due to limited resources, some enterprises in the industry may choose strategies with large strategic difference degrees. According to the leverage principle, to some extent, the greater the strategic difference degree of an enterprise, the greater the operational uncertainty of the enterprise will be. The innovation and contribution of this paper are as follows: (1) from the theoretical and empirical point of view, it provides suggestions for the formulation of enterprise strategy, so that the revision of enterprise strategy can help improve enterprise performance as much as possible. (2) This paper introduces industry competition degree as an explanatory variable to explore the influence of strategic difference degree on enterprise performance under different industry competition degree. Based on the above analysis, this paper focuses on the impact of enterprise strategic difference degree and industry competition degree on enterprise performance.

\section{LITERATURE REVIEW}

\subsection{A Review of Three Factors Research Trends}

Wang Huacheng took a-share listed companies in Shanghai and Shenzhen as the sample data, and the empirical research results showed that the degree of strategic difference was positively correlated with the cost of equity capital, among which operating risk and information asymmetry played A moderating role.

Gao Feng used the data of China's listed manufacturing companies from 2013 to 2001 to study the positive correlation between the integration degree of supply chain and the financial performance of core manufacturing.

$\mathrm{Lu}$ Xiaodong's research found that enterprises combine financial and non-financial indicators more effectively when evaluating performance, so as to eliminate errors and give full play to the advantages brought by index evaluation.

Chen Xiao and Jiang Dong found that only by improving the competitiveness of the industry can the advantages of the policy of diversification of the ownership structure of state-owned enterprises be brought into full play to improve the company's business performance.

\subsection{Domestic and Foreign Literature Review}

By summarizing domestic and foreign literature review, the existing literature mainly studies the economic impact and influencing factors of strategic difference degree and industry competition degree, and how to measure enterprise performance, etc. However, there is a lack of research on the relationship between 
strategic difference degree and enterprise performance and the impact of industry competition degree on enterprise performance. Therefore, this paper tries to find a new research perspective after combing and analysing the previous literature.

\section{HYPOTHESES AND DATA SOURCES}

\subsection{Hypothesis Formulation}

The enterprise strategy difference degree and industry competition degree are two factors which must be considered in enterprise operation. Obviously, the greater the strategic difference degree is, the higher the risk will be, the more uncertainties will be faced in the operation. Similarly, when an enterprise tries a new strategy, there is no previous experience of success or failure to refer to, and there is still uncertainty as to whether the new strategic model is suitable for the development of the market while risks increase. If we choose the strategy of stable and steady development with the industry when formulating the strategy, it may make the operation relatively stable, gradually improve and enhance the performance, and finally make a fortune silently.

Based on the above analysis, we propose hypothesis 1: the greater the difference of enterprise strategy, the smaller the enterprise performance.

It is relatively easy to increase sales in a growing and open market, but it is difficult to expand market share in a saturated market. The more fierce competition, the more difficult it is to increase sales. Obviously, the size of industry competition degree will directly or indirectly affect sales, and may eventually increase or decrease enterprise performance.

Based on the above analysis, we propose hypothesis 2: the greater the industry competition degree, the smaller the enterprise performance.

\subsection{Data Source}

The data used in this paper are mainly from CSMAR database of China Tai 'an. A-share listed companies from 1996 to 2016 are selected as research samples and *ST companies and companies with missing data are excluded. In the analysis, 6049 enterprise-year observations were retained after missing and abnormal data were removed. The data processing and analysis in this paper are processed by Excel and STATA statistical software.

\section{VARIABLE SELECTION AND MODEL CONSTRUCTION}

\subsection{Variable Selection}

\subsubsection{Explained Variables}

Enterprise performance is generally measured by Tobin's Q or accounting profit indicators, such as return on assets (ROA) and return on net assets (ROE).In this paper, ROA is used to measure the level of enterprise performance. The larger ROA is, the better enterprise performance is, and vice versa.

\subsubsection{Explanatory Variables}

The explained variable strategy difference degree (DS) has six indicators in Table 1. Since complete data cannot be obtained on advertising expenses, this paper uses two new indicators, namely sales expenses and net intangible assets, to replace advertising expenses and R\&D expenses. First of all, after the data is collected, the average value of the six sorted indicators is subtracted from the industry accounting period, divided by the standard deviation of the industry data in the corresponding accounting period, and all positive numbers are taken. Finally, the average value of the six indicators is taken to obtain a comprehensive value.

Herfindahl-hirschma index (HHI) is used in this paper to measure the industry competition index. The smaller $\mathrm{HHI}$ is, the more competitive the industry competition is. On the contrary, the larger HHI is, the more serious the monopoly is, the less the industry competition is.

Table 1 Measurement indicators of strategic difference degree

\begin{tabular}{|c|c|}
\hline Indicators & A formula to calculate \\
\hline advertising & $\begin{array}{c}\text { Sales expenses/operating } \\
\text { income }\end{array}$ \\
\hline $\begin{array}{c}\text { Research and } \\
\text { development efforts }\end{array}$ & $\begin{array}{c}\text { Net intangible assets/operating } \\
\text { income }\end{array}$ \\
\hline $\begin{array}{c}\text { Capital density } \\
\text { Total fixed assets/number of } \\
\text { employees }\end{array}$ \\
\hline $\begin{array}{c}\text { Renewal of fixed } \\
\text { assets }\end{array}$ & $\begin{array}{c}\text { Net fixed assets/total fixed } \\
\text { assets }\end{array}$ \\
\hline $\begin{array}{c}\text { Management cost } \\
\text { efficiency }\end{array}$ & Overhead/operating income \\
\hline Financial leverage & Total liabilities/owners' equity \\
\hline
\end{tabular}




\subsubsection{Control Variables}

The control variables in this paper include property right (Soe), enterprise financial characteristic variable (Size), Inventory ratio, fixed asset ratio (PPE), assetliability ratio (LEV), equity concentration (Share), book-to-market ratio (BM) and Duality.

\subsection{Model Construction}

In order to test the research hypothesis proposed in this paper, the following multiple regression model is established: the measurement index of the explained variable is enterprise performance (ROA), and the measurement index of the explained variable is the measurement index of strategic difference degree and industry competition degree. Control variables include: Enterprise financial characteristic variable (Size), assetliability ratio(LEV), inventory radio and so on. The multiple regression analysis model of strategic difference degree, industry competition degree and enterprise performance can be expressed as follows:

Roa $=\beta_{0}+\beta_{1} \mathrm{DS}+\beta_{2} \mathrm{HHI}+\beta_{3}$ Controls + Fixed effects $++\varepsilon$ (1)

Then, based on the data, descriptive analysis, and multiple linear regression analysis of relevant variables were conducted using statistical software to verify the hypothesis.

\section{THE EMPIRICAL RESULTS}

\subsection{Descriptive Analysis}

Descriptive analysis was conducted on all the variables selected above, and the results were shown in Table 2. From Table 2, minimum and maximum values of sample data respectively. From the results of the descriptive analysis, we can see that: (1) The mean value of strategic difference degree is 0.511351 . The minimum value of strategic difference degree is 0.00856 , indicating that the strategic difference degree is very small; the maximum value is 11.3363 , indicating that the strategic difference degree is very large. The difference between the maximum value and minimum value of strategic difference degree is 11 , indicating that the strategic difference degree is very large, and some companies have extreme situations when formulating enterprise strategies.(2) The mean value of the industry competition degree is 0.087919 , indicating that the competition degree of most industries is large; the minimum value is 0.018657 , indicating that the industry competition degree is large; the maximum value is 1 , indicating that the industry competition degree is small; the maximum value and minimum value differ greatly, indicating that the industry competition degree and monopoly degree are different in different industries.(3) The minimum value of the enterprise's performance is 0.18782 , indicating that the performance can sometimes be negative. The maximum value is 0.159663 , indicating that the return on assets level is good. The mean value is 0.015654 .

\subsection{Multiple Linear Regression Analysis}

According to the results of regression analysis, the value of mathematical model R-Squared is 0.023 . It can be seen from Table 3 that all p-values of the models are less than 0.1 , so this model is significant and statistically significant. On the basis of controlling year and industry, this paper conducts the next step multiple linear regression analysis for the relationship between strategic difference degree and industry competition degree and enterprise performance. Considering the control variables, the above regression results show that strategic difference degree and enterprise performance is a negative correlation between both, and the result is significant under $1 \%$, that the variables of the model test was a significant impact, verify the hypothesis 1 was established, the greater the strategic difference degree, the lower the enterprise performance.

There is a positive correlation between industry competition degree and enterprise performance, which is significant at the level of $5 \%$. Hypothesis 2 is established, that is, the smaller the industry competition degree is, the greater the enterprise performance is. In addition, it can be seen from the results in the table that enterprise size and enterprise nature also have a significant impact on enterprise performance.

Table 2. Descriptive analysis table

\begin{tabular}{|c|c|c|c|c|c|}
\hline variable & observations & The average & $\begin{array}{c}\text { The standard } \\
\text { deviation }\end{array}$ & $\begin{array}{c}\text { The minimum } \\
\text { value }\end{array}$ & $\begin{array}{c}\text { The maximum } \\
\text { Value }\end{array}$ \\
\hline Share & 6049 & 0.6912819 & 0.265487 & 0.05824 & 1 \\
\hline Size & 6049 & 0.976115 & 0.037579 & 0.8068 & 1.0988 \\
\hline LEV & 6049 & 0.38061 & 0.1277 & 0.0501 & 0.940 \\
\hline PPE & 6049 & 0.11344 & 0.56232 & 0 & 0.751 \\
\hline Inventory & 6049 & 0.09962694 & 0.37103 & 0 & 0.836 \\
\hline Soe & 6049 & 0.637461 & 0.480773 & 0 & 1 \\
\hline Duality & 6049 & 0.223174 & 0.4345 & 0 & 1.745 \\
\hline BM & 6049 & 0.665644 & 0.34767 & 0.005 & 11.3363 \\
\hline DS & 6049 & 0.511351 & 0.408046 & 0.008569 & 1 \\
\hline HHI & 6049 & 0.087919 & 0.111923 & 0.018657 & 0.159663 \\
\hline
\end{tabular}


Table 3 Multivariate linear regression analysis table

\begin{tabular}{|c|c|c|c|}
\hline Variable & Coefficient & T-value & P-value \\
\hline DS & -0.0047717 & -3.511 & $-0.0048^{* * *}$ \\
\hline HHI & 0.0107671 & 2.169 & $0.0108^{* *}$ \\
\hline first & -0.0000163 & -0.788 & $0.0430^{* *}$ \\
\hline Size & 0.335793 & 2.291 & $0.0336^{* *}$ \\
\hline LEV & $-4.33 \mathrm{E}-07$ & -0.691 & 0.490 \\
\hline PPE & $5.44 \mathrm{E}-07$ & 0.54 & 0.589 \\
\hline Inventory & $-6.13 \mathrm{E}-07$ & -0.097 & 0.923 \\
\hline Soe & 0.0008857 & 0.774 & 0.928 \\
\hline BM & $3.03 \mathrm{E}-06$ & 0.09 & -0.0151 \\
\hline Constant & -0.0150629 & -1.046 & control \\
\hline year & control & control & control \\
\hline industry & control & control & \\
\hline Observations & 6,049 & & \\
\hline Adjusted R-squared & 0.023 & & \\
\hline R-squared & 0.038 & & \\
\hline
\end{tabular}

Note: $* * * \mathrm{P}<0.01, * * \mathrm{P}<0.05, * \mathrm{P}<0.1$

\section{CONCLUSION AND SUGGESTION}

\subsection{Conclusion}

In today's fierce market, enterprises choose steady development but can improve and enhance corporate performance. Many people believe that it is a successful performance for an enterprise to achieve the growth of its performance through continuous mergers and acquisitions, crossover and expansion. However, if an enterprise fails to gain a firm foothold in the new field and improve its performance, such diversified growth will actually consume the company's capacity. Today, many Chinese enterprises are facing the problem of market saturation, and it is much more difficult to expand market share in a saturated market. When the industry competition is lower, enterprise performance is more likely to be higher.

\subsection{Suggestion}

\subsubsection{First Gain a Firm Foothold in the Industry}

In a saturated market, we should pay more attention to how to maintain a stable footing in the industry. Now that China's economy has entered a new normal and many industries have accounted for more than $40 \%$ of the global share, we should reflect on what is the most appropriate strategy. Because the time interval between the discovery of a dangerous situation and the impact on the enterprise performance must be less than the time needed to revise the strategic difference degree, it is too late to rethink the formulation of strategy when a large loss has occurred.

\subsubsection{Focus on Long-term Sustained Growth}

A new thing from the emergence to development to growth must have a process. What we need is to make an accurate judgment on the events that have happened in the industry and seek benefits at the right time, instead of pursuing a large degree of strategic difference, which will eventually lead to a larger degree of Strategic difference and a smaller performance. We should pay attention to long-term development.

\section{REFERENCES}

[1] Wang Huacheng, Liu Junyong. Research on the Model of enterprise performance evaluation -Also choice of Chinese enterprise performance evaluation Model [J].Management World, 2004(04):82-91.

[2] Gao Feng.Impact of Supply Chain Integration on Financial Performance [D]. Shandong University, 2018.

[3] Lu Xiaodong. Discussion on the Application of non-financial Indicators in Enterprise Performance Evaluation System [J]. Accounting for Township Enterprises in China, 2020(04):98-99.

[4] Chen Xiao, Jiang Dong. Equity diversification, enterprise performance and industry competitiveness [J].Economic Research Institute, 2000(08):28-35. 